\title{
Evaluation of Agronomic Performance of Maize (Zea mays L.) under a Fertilization Gradient in Transylvanian Plain
}

\author{
Gabriel Barșon ${ }^{1}$, Laura Șopterean ${ }^{2}$, Loredana Alexandra Suciu ${ }^{1,2}{ }^{*}$, Ioana Crișan ${ }^{1}$ (D) and Marcel Matei Duda ${ }^{1}$ (D) \\ 1 Faculty of Agriculture, University of Agricultural Sciences and Veterinary Medicine, Calea Mănăștur 3-5, \\ 400372 Cluj-Napoca, Romania; gabrielbarson@gmail.com (G.B.); ioana.crisan@usamvcluj.ro (I.C.); \\ marcel.duda@usamvcluj.ro (M.M.D.) \\ 2 Agricultural Research and Development Station, Agriculturii Street 27, 401100 Turda, Romania; \\ soptereanlauramaria@gmail.com \\ * Correspondence: loredana.suciu@usamvcluj.ro
}

Citation: Barșon, G.; Șopterean, L.; Suciu, L.A.; Crișan, I.; Duda, M.M. Evaluation of Agronomic Performance of Maize (Zea mays L.) under a Fertilization Gradient in Transylvanian Plain. Agriculture 2021, 11, 896. https://doi.org/ 10.3390/agriculture11090896

Received: 19 August 2021 Accepted: 14 September 2021 Published: 18 September 2021

Publisher's Note: MDPI stays neutral with regard to jurisdictional claims in published maps and institutional affiliations.

Copyright: (c) 2021 by the authors. Licensee MDPI, Basel, Switzerland. This article is an open access article distributed under the terms and conditions of the Creative Commons Attribution (CC BY) license (https:// creativecommons.org/licenses/by/ $4.0 /)$.

\begin{abstract}
In the last few years, Romania has become a top maize producer. Export potential is sustained by ensuring high-quantity and -quality maize. Success of maize crop is highly dependent on inputs. In this context, insight into the potential of different fertilizers to maximize crop performance could shed light on best practices to enhance yields and other traits of interest. The aim of this study was to assess the agronomic performance of maize under a fertilization gradient. Six fertilizer regimes were tested on three maize hybrids between 2018 and 2020, in conditions from the Transylvanian Plain. Results showed that fertilization had a significant influence on yield, thousand kernels weight, grain quality (starch and protein content) and crop health. The experimental year also played a significant role in the expression of productivity potential of maize genotypes. Different fertilizer regimes could be used for targeting desired outcomes, but top performance across all or multiple agronomic components remains a challenge and should receive further attention for optimization.
\end{abstract}

Keywords: corn hybrids; yield; starch; protein; Fusarium sp.; Ostrinia nubilalis

\section{Introduction}

Romania has been among the top 10 producers of maize worldwide since 2018 according to the Food and Agriculture Organization of the United Nations [1] and the most important maize grower within the European Union according to Eurostat [2]. Statistics from the Ministry of Agriculture and Rural Development from Romania indicate that, since the integration in the European Union, both the average yield-per-unit area as well as total production of maize increased at the national level [3], presenting attractive export potential. The possibility to increase exports is relying on the optimization of maize crop performance, in order to ensure high-quantity and -quality maize.

Yield of maize crop is to a high extent dependable on the application of fertilizers $[4,5]$, and will continue to be so in the foreseeable future. Out of the nutrients required for crop growth, N (Nitrogen), as well as P (Phosphorus), and K (Potassium), are considered the most consequential for successful cultivation of maize [5-9]. It is standard knowledge that adequate fertilization is essential for realizing maize hybrid yield potential, but nutrient application has to be conducted both on sustainable environmental and financial considerations [10]. Yields can be obtained in a sustainable manner through balanced nutrition, which ensures adequate uptake of both macronutrients as well as micronutrients by the plants and that, in turn, ensure grains that are healthy, biofortified and nutritious [11]. Because optimal nutrient supply of the plants is related to health of the crop, it can be considered a component of Integrated Pest Management [12]. For maize crop, the pattern of nutrient uptake can vary in time, rate and duration, while also varying with each specific nutrient and its plant part where it is allocated [10]. Grain yield and nutrients accumulation in kernels are chiefly influenced by genotype and nutrients available in soil [8]. 
Rapid scientific advances in soil-plant interactions from recent years have generated a ripple effect for trends on fertilizers market. As a consequence, farmers today are presented with a variety of options that promise success for their crops. From mineral to organic components, besides various formulations that stimulate soil biota or plant performance, the list of options is expanding. However, clearly defined agronomic benefits of fertilization regimes following a comparative approach can highlight best practices in connection with desired outcomes, as well as areas that need further optimization. Understanding the behavior of widely used or new maize hybrids under novel fertilization regimes could help in identifying potential particularities that might affect nutrient recommendations in regards to timing and rate. Since sustainable stewardship of nutrient use in agriculture is at the nexus of successful crop-environment-economic efficiency [10,13], investigation into interaction between environment, genotypes and fertilization on agronomic outcomes becomes an indispensable approach for food security.

The aim of this research was to provide an evaluation of maize performance under a fertilization gradient, by screening a range fertilizer regime. The results are meant to provide insight into the performance potential of newly trended options to enhance productivity components, compared to the traditional basal complex fertilizer + calcium ammonium nitrate, a fertilization regime well established in agronomic practice for the past few decades. The objective of the research was to evaluate the influence of experimental factors and gradients on the following: plant growth, maize ear disease and pest's incidence, on plant quantitative and qualitative productivity components.

\section{Materials and Methods}

\subsection{Location and Pedo-Climatic Conditions}

The experiment was conducted at Agricultural Research and Development Station (ARDS) fields from Turda, Romania, situated at latitude 46.35, longitude 23.47 and altitude 345-493 m [14]. The ARDS Turda is situated in the Transylvanian Plain, characterized by hilly landscape $[15,16]$. Between hills, there are valleys oriented mainly on the direction east-west, with naturally poor drainage $[17,18]$. The characteristic landforms of this area are gentle and moderate slopes subject to erosion processes [14]. According to ARDS Turda, arable farming land presents a gentle sloping gradient (3-5\%).

The climate is continental temperate with four seasons. According to Köppen-Geiger classification, Turda has a humid continental climate [19].

Weather data from the experimental years are presented in Figure 1, alongside with average values for the last 60 years, as registered at the weather station of ARDS Turda.

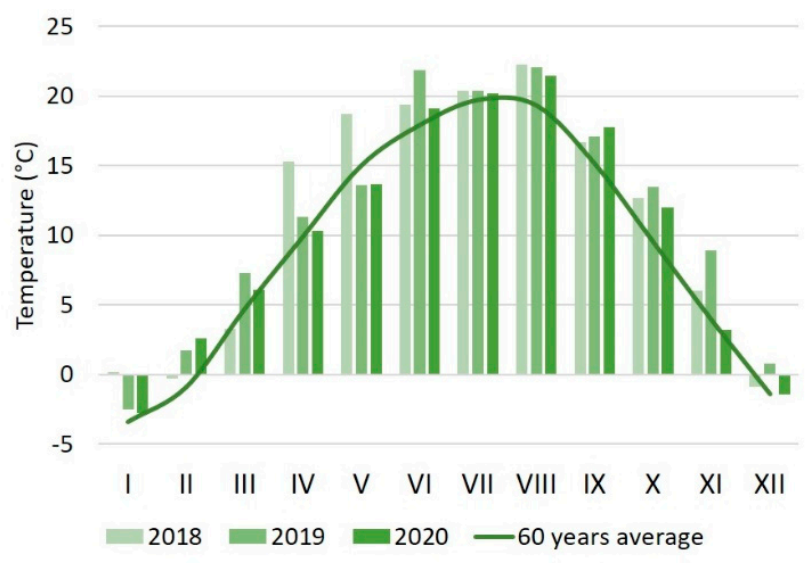

(a)

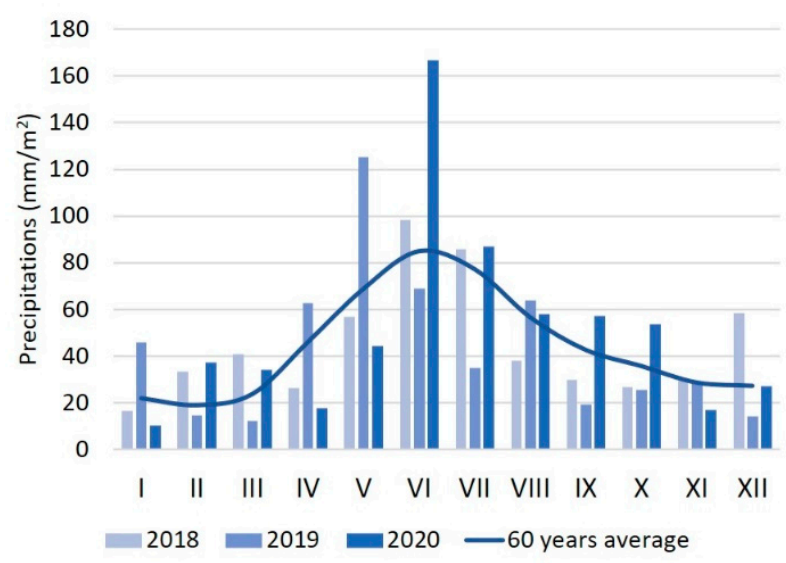

(b)

Figure 1. Weather conditions during the experiment (2018-2020), (a) average monthly temperatures; (b) monthly sum of precipitations; according to ARDS Turda weather station situated at longitude $23^{\circ} 47^{\prime}$, latitude $46^{\circ} 35^{\prime}$ altitude $427 \mathrm{~m}$. 
During the entire maize growing season (April-September), the average monthly temperatures in the year 2018 exceeded the 60-year average. Also, during the months of April until August, the average monthly temperatures were highest in 2018 compared to the other two experimental years.

Regarding precipitations, one can observe that the year 2019 experienced the highest precipitations during the spring months out of the three experimental years, as well as exceeding the multiannual average, but was lowest in precipitations during the months of June-July. By comparison, the year 2020 experienced lower precipitations than the multiannual average or the other two previous experimental years in the months of April-May, but afterwards, the precipitations were more abundant, reaching the highest levels in June-July.

The soil type is Phaeozem and having the following average values of agrochemical indices determined at depth of 0-30 cm: pH 7.00, humus 3.40\%, Nitrogen $0.226 \%$, Phosphorus 73 ppm, Potassium 295 ppm [20].

\subsection{Organization of the Experiment}

The experiment was located in the field at ARDS Turda and had the following factors:

- Factor Y (the experimental years) with three levels:

$$
\begin{aligned}
& \text { Y1-2018; } \\
& \text { Y2-2019; } \\
& \text { Y3-2020. }
\end{aligned}
$$

- Factor $\mathrm{H}$ (the hybrid) with three levels:

$$
\begin{aligned}
& \text { H1-Turda 332; } \\
& \text { H2-Turda 344; } \\
& \text { H3-PR37N01. }
\end{aligned}
$$

- $\quad$ Factor F (fertilization) with six levels:

$$
\begin{aligned}
& \text { F1-Basal + CAN (Calcium ammonium nitrate })=\left(\mathrm{N}_{67.5} \mathrm{P}_{33.75}\right)+\left(\mathrm{N}_{54}\right) ; \\
& \text { F2-Eurofertil Top 51 NPK + CAN }=\left(\mathrm{N}_{10} \mathrm{P}_{25} \mathrm{~K}_{50} \mathrm{~S}_{42.5} \mathrm{Mg}_{5}\right)+\left(\mathrm{N}_{54}\right) ; \\
& \text { F3-Basal + Synertec NK35 N-process }=\left(\mathrm{N}_{67.5} \mathrm{P}_{33.75}\right)+\left(\mathrm{N}_{50} \mathrm{~K}_{20} \mathrm{~S}_{42} \mathrm{Zn}_{0.4} \mathrm{~B}_{0.4}\right) ; \\
& \text { F4-Basal + CAN + Fertiactyl Starter }=\left(\mathrm{N}_{67.5} \mathrm{P}_{33.75}\right)+\left(\mathrm{N}_{54}\right)+\text { Biostimulator; } \\
& \text { F5-Basal + CAN + Rootip Basic + Energevo }=\left(\mathrm{N}_{67.5} \mathrm{P}_{33.75}\right)+\left(\mathrm{N}_{54}\right)+\text { Rooting } \\
& \text { Biostimulator + Foliar fertilizer with microelements; } \\
& \text { F6-NovaTec Classic }=\mathrm{N}_{24} \mathrm{P}_{16} \mathrm{~K}_{32} \mathrm{Mg}_{6} \mathrm{~S}_{18} \text { and microelements. }
\end{aligned}
$$

The fertilization products were obtained from the companies Naturevo [21] and Timac Agro [22] from Romania. The description of the products according to the label is provided in Table 1. The products were chosen in order to cover a diverse range: both the classic, frequently used products as well as novel fertilization products. The rate of application of the products is mentioned in Table 1. 
Table 1. Fertilization products used for different combinations and their composition.

\begin{tabular}{|c|c|c|c|c|}
\hline Fertilizer & Contents ${ }^{1}$ & Chemical Composition ${ }^{1}$ & $\begin{array}{c}\text { Application/ } \\
\text { BBCH Stage [23] }\end{array}$ & Dose Used \\
\hline Basal complex & NP 27:13.5 & $27 \% \mathrm{~N} ; 13.5 \% \mathrm{P}$ & $\begin{array}{l}\text { at sowing } \\
\text { (stage 00-01) }\end{array}$ & $250 \mathrm{~kg} / \mathrm{ha}$ \\
\hline Eurofertil Top 51 NPK & $\begin{array}{l}\text { NPK }+ \text { other elements } \\
(\mathrm{Ca}, \mathrm{Mg}, \mathrm{S}, \mathrm{B}, \mathrm{Zn})\end{array}$ & $\begin{array}{l}4 \% \mathrm{NH}_{4} ; 27.2 \% \mathrm{P}_{2} \mathrm{O}_{5} ; 20 \% \mathrm{~K}_{2} \mathrm{O} \\
2 \% \mathrm{MgO} ; 17 \% \mathrm{SO}_{3} ; 12 \% \mathrm{CaO} \\
0.2 \% \mathrm{~B} ; 0.15 \% \mathrm{Zn}\end{array}$ & $\begin{array}{l}\text { at sowing } \\
\text { (stage 00-01) }\end{array}$ & $250 \mathrm{~kg} / \mathrm{ha}$ \\
\hline NovaTec Classic & $\begin{array}{l}\text { NPK 12:8:16 + other } \\
\text { elements }(\mathrm{Mg}, \mathrm{S}, \mathrm{B}, \mathrm{Fe} \\
\text { Zn) + nitrifying } \\
\text { inhibitors }\end{array}$ & $\begin{array}{l}12 \% \mathrm{~N}\left(5.0 \% \mathrm{NO}_{3}+7.0 \% \mathrm{NH}_{4}\right) \\
8.0 \% \mathrm{P}_{2} \mathrm{O}_{5} ; 16.0 \% \mathrm{~K}_{2} \mathrm{O} ; 3.0 \% \\
\mathrm{MgO} ; 10 \% \mathrm{SO}_{3} ; 0.02 \% \mathrm{~B} ; 0.06 \% \\
\mathrm{Fe} ; 0.01 \% \mathrm{Zn} ; 0.056 \% \mathrm{DMPP} \\
\text { (3,4-dimethylpyrazole } \\
\text { phosphate) }\end{array}$ & $\begin{array}{l}\text { at sowing } \\
\text { (stage 00-01) }\end{array}$ & $200 \mathrm{~kg} / \mathrm{ha}$ \\
\hline CAN & $\begin{array}{l}\text { Calcium ammonium } \\
\text { nitrate: } \mathrm{N}+\text { other } \\
\text { elements }(\mathrm{Ca}, \mathrm{Mg})\end{array}$ & $27 \% \mathrm{~N} ; 7 \% \mathrm{CaO} ; 5 \% \mathrm{MgO}$ & $\begin{array}{l}\text { 4-8 leaves } \\
\text { (stage } 14-18 \text { ) }\end{array}$ & $200 \mathrm{~kg} / \mathrm{ha}$ \\
\hline $\begin{array}{l}\text { Synertec NK35 } \\
\text { N-process }\end{array}$ & $\begin{array}{l}\text { NK + other elements }(\mathrm{S}, \\
\mathrm{B}, \mathrm{Zn})\end{array}$ & $\begin{array}{l}25 \% \mathrm{~N} ; 10 \% \mathrm{~K}_{2} \mathrm{O} ; 21 \% \mathrm{SO}_{3} ; 0.2 \% \\
\mathrm{Zn} ; 0.2 \% \mathrm{~B}\end{array}$ & $\begin{array}{l}\text { 4-8 leaves } \\
\text { (stage } 14-18)\end{array}$ & $200 \mathrm{~kg} / \mathrm{ha}$ \\
\hline Energevo & $\begin{array}{l}\text { NPK 9:53:9 + other } \\
\text { elements }(\mathrm{Mg}, \mathrm{B}, \mathrm{Fe} \text {, } \\
\mathrm{Mn}, \mathrm{Mo}, \mathrm{Cu}, \mathrm{Zn})\end{array}$ & $\begin{array}{l}9 \% \mathrm{~N} ; 53 \% \mathrm{P}_{2} \mathrm{O}_{5} ; 9 \% \mathrm{~K}_{2} \mathrm{O} ; 1 \% \mathrm{~S} ; \\
2.5 \% \mathrm{MgO} ; 0.1 \% \mathrm{~B} ; 0.1 \% \mathrm{Fe} \\
0.05 \% \mathrm{Mn} ; 0.1 \% \mathrm{Zn} ; 0.05 \% \mathrm{Cu} ; \\
0.005 \% \mathrm{Mo}\end{array}$ & $\begin{array}{l}\text { 4-8 leaves } \\
\text { (stage } 14-18 \text { ) }\end{array}$ & $3 \mathrm{~kg} / \mathrm{ha}$ \\
\hline Fertiactyl Starter & NPK 13:5:8 & $\begin{array}{l}13 \% \mathrm{CO}\left(\mathrm{NH}_{2}\right)_{2} ; 5 \% \mathrm{P}_{2} \mathrm{O}_{5} ; 8 \% \\
\mathrm{~K}_{2} \mathrm{O}\end{array}$ & $\begin{array}{l}\text { 4-8 leaves } \\
\text { (stage } 14-18)\end{array}$ & $3 \mathrm{~L} / \mathrm{ha}$ \\
\hline Rootip Basic & $\begin{array}{l}\text { NK }+ \text { amino acids }+ \\
\text { phytohormone } \\
\text { precursors (of auxin, } \\
\text { cytokinin) }\end{array}$ & $\begin{array}{l}9 \% \mathrm{~N}\left(3.9 \% \mathrm{NO}_{3}, 3.9 \% \mathrm{NH}_{4},\right. \\
1.2 \% \text { organic nitrogen); } 1.7 \% \\
\mathrm{~K}_{2} \mathrm{O} ; 7.8 \% \text { amino acids; } 7 \% \\
\text { organic matter }\end{array}$ & $\begin{array}{l}\text { 4-8 leaves } \\
\text { (stage } 14-18)\end{array}$ & $1.5 \mathrm{~L} / \mathrm{ha}$ \\
\hline
\end{tabular}

${ }^{1}$ According to label of the products.

The fertilization regime was comprised by basal complex fertilization and calcium ammonium nitrate application has been most commonly used in Romania by farmers and selected as control for the comparative analysis of productivity components. Out of the six fertilizer regimes tested, F6 was the only one that did not involve also phasic application.

Two of the maize hybrids studied were created at ARDS Turda (H1, H2) [24], while the third one (H3) was created by Pioneer [25]. All three hybrids were created to be cultivated for grains and belong to the same FAO maturity group (380). PR37N01 is the most cultivated maize hybrid from Pioneer in the Transylvanian Plain, while the other two maize hybrids (Turda 332; Turda 344) are among recent creations of the ARDS Turda.

Descriptions of the maize hybrids according to the breeders are the following:

- "Turda 332" has good resistance to drought and shriveling of kernels. Plants are tall with 16-17 leaves. The ear is long with a cylindrical shape, having 18-22 rows and red rachis. Kernels are dentate with a dark yellow color. Thousand kernels weight is between 220 and $240 \mathrm{~g}$ [24].

- "Turda 344" is characterized by high productivity potential of $14 \mathrm{t} / \mathrm{ha}$, good resistance to low temperatures during first growth stages. Plants are tall, reaching $3.30 \mathrm{~m}$ in height, and ear insertion is between 1.20 and $1.30 \mathrm{~m}$. It is stay-green hybrid. The ear has 18-29 rows and thousand kernels weight of 300-320 g. Kernels are dentate [24].

- "PR37N01" is a hybrid with stable yields and resistant to drought, lodging and main maize crop pests and diseases. It has balanced height and medium-high ear insertion. The ear has 16-18 rows and 37-41 kernels per row. It is a stay-green maize hybrid [26].

The maize crop was cultivated under a conventional system. Sowing was performed in May, and maize was harvested in October. Plant density was 57,000/ha. No herbicides, 
pesticides or any disease control agents were used. Weed control was performed only mechanically.

The experimental variants were organized according to a randomized block design (Figure 2) in field conditions. There were three repetitions in the field, and the experiment took place during the span of three years (2018-2020). Each variant in each repetition had four rows of plants, and all determinations were conducted on the plants from the two rows in the middle.

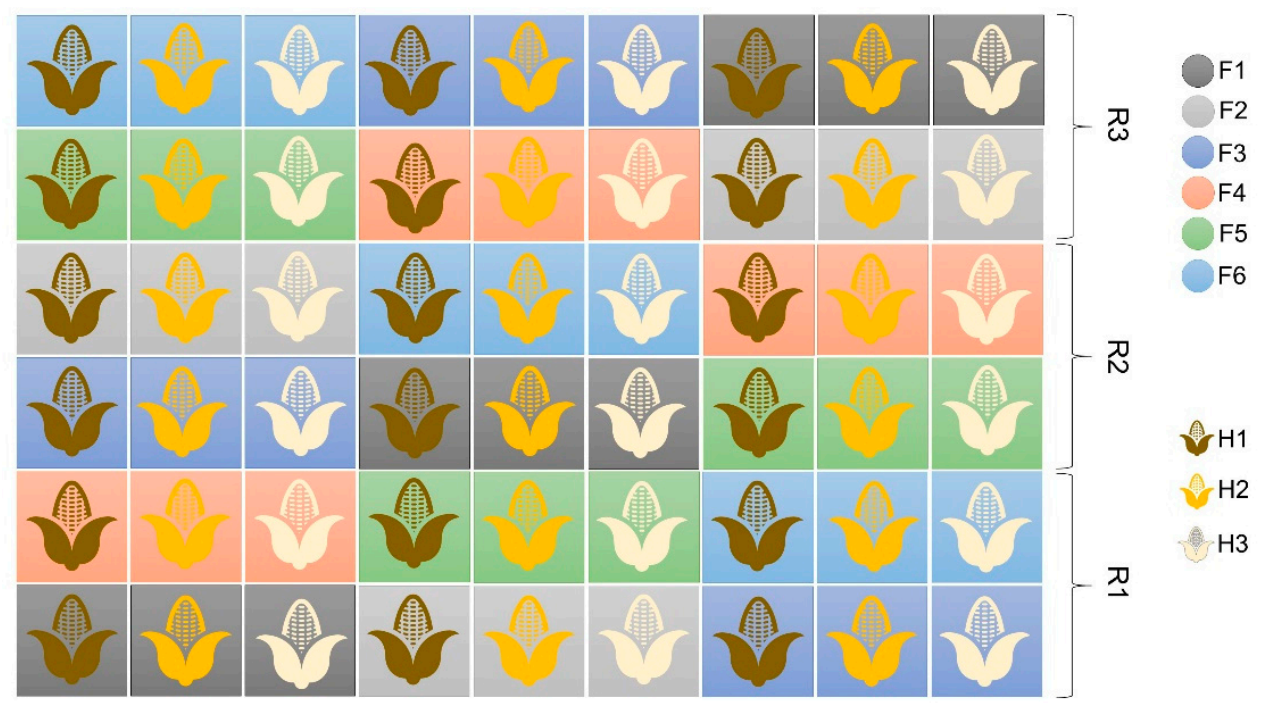

Figure 2. Planting plan of experimental maize crop at ARDS Turda (2018-2020), where "F1-F6" indicates fertilization gradient, "H1-H3" the three maize hybrids tested, "R1-R3" the repetitions.

\subsection{Determinations}

During vegetation and after harvest, several determinations were conducted. Thus, 12 agronomic components were quantified in the three experimental years. These were:

- plant characteristics: plant height (m), ear insertion height (m), leaf length (m), leaf width $(\mathrm{cm})$, leaves number above ear.

- quantitative productivity parameters: thousand kernels weight (TKW g), hectoliter mass (HLM kg/hl), yield (kg/ha).

- $\quad$ qualitative parameters of maize grains: starch content (\%), protein content (\%).

- $\quad$ disease and pest's incidence on maize ears: Fusarium sp. and Ostrinia nubilalis frequency $(\%)$.

Plant characteristics were determined by measurements in the field, for ten plants from each variant in the month of August when plants were in full maturity, after the browning of the silk. After harvesting the maize in October, the hectoliter mass was determined using Granomat equipment [27], while grain quality parameters were determined with NIR Tango spectrophotometer [28]. Yield was determined following manual harvest and weighing, followed by correction at STAS humidity of $15 \%$.

Disease incidence was calculated as frequency (1) for maize ears according to standard methodology [29]:

$$
\text { incidence }=\frac{\text { infected or infested maize ears }}{\text { total number of ears analyzed }} \times 100
$$

\subsection{Statistical Analysis}

Data were analyzed for each of the 12 agronomic components by applying three-way ANOVA and using Origin software by OriginLab [30]. Significant influence of bipartite interaction between factors over a given agronomic component was further explored using 
POLIFACT (non-commercial software) by applying post hoc tests: either Duncan test or the Fishers' Least Significance Difference test. The influence of experimental gradients on each of the agronomic components are presented in Supplementary File 1.

\section{Results}

Analysis revealed that experimental factors, their interactions and their gradients had a different influence on the agronomic components of maize, ranging from highly significant to not significant.

\subsection{Characteristics of Plants}

All maize plant characteristics were highly significantly influenced by experimental years. The hybrid exercised a highly significant influence on three plant traits: plant height, ear insertion and leaf length (Figure 3).

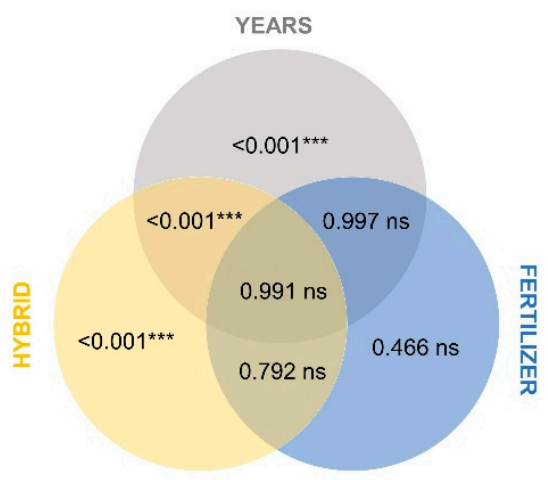

Plant height

(a)

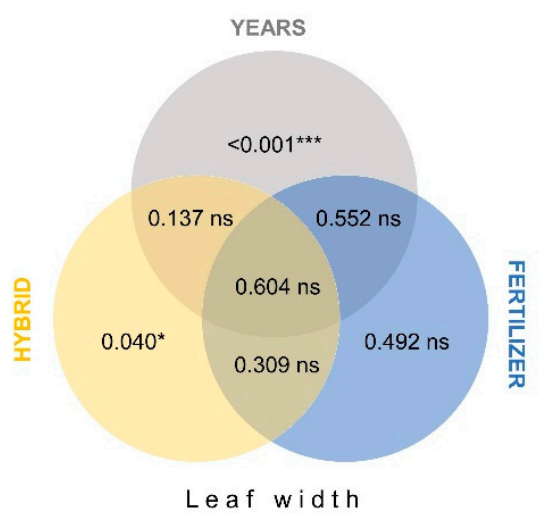

(d)

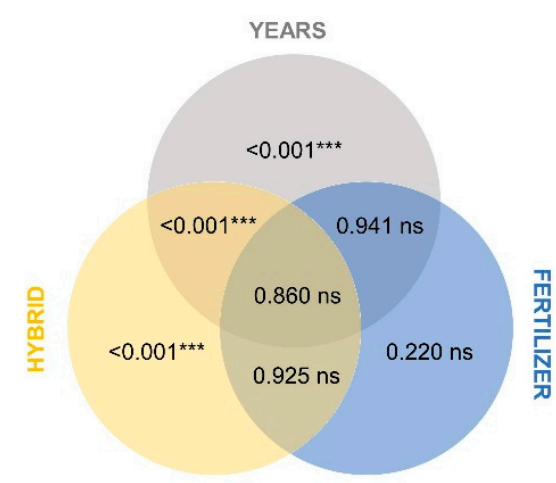

Ear insertion

(b)

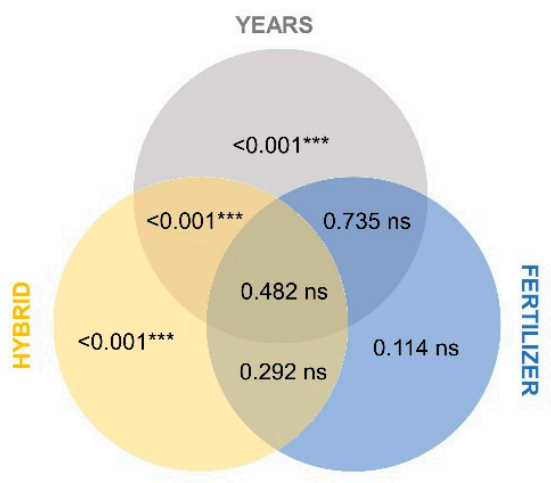

Leaf length

(c)

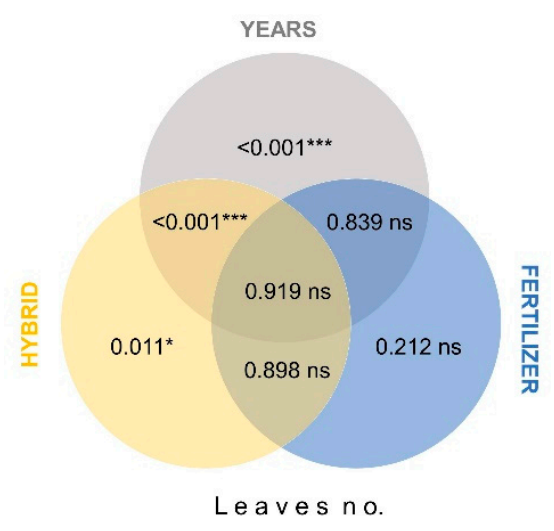

(e)

Figure 3. Venn diagram depicting the influence of experimental factors and their interaction on maize plant characteristics: (a) plant height; (b) ear insertion; (c) leaf length; (d) leaf width; (e) leaves number. Numbers represent $p$-values according to three-way ANOVA results; significance levels assigned $p>0.05$ (ns), $p<0.05\left(^{*}\right), p<0.001{ }^{* * *}$ ).

The fertilization treatments and interaction between fertilization treatment and experimental years did not exercise a significant influence over the maize plant characteristics. Also, tripartite interaction between the factors did not significantly influence the plant morphometric traits (Figure 3).

There were registered differences in value under different fertilization treatments. The tree-year average was highest for plant height $(2.63 \pm 0.21 \mathrm{~m})$ and ear insertion height $(1.12 \pm 0.13 \mathrm{~m})$ under fertilization with Eurofertil Top 51 NPK + CAN. Longest leaves 
$(0.89 \mathrm{~m})$ were obtained by applying Eurofertil Top $51 \mathrm{NPK}+\mathrm{CAN}$ as well as Basal + Synertec NK35 N-process. Highest number of leaves above ear (5.57 \pm 0.38$)$ was obtained by applying NovaTec Classic. Widest leaves $(9.47 \mathrm{~cm})$ were obtained by applying Basal + Synertec NK35 N-process as well as Basal + CAN + Rootip Basic + Energevo (Table S1).

Under the influence of experimental years, the plant morphometric characteristics of the hybrids displayed a variation. In the year 2018, as well as in 2019, the hybrid "Turda 344 " had the tallest plants and highest ear insertion, while in 2020, the hybrid "Turda 332" presented the highest values for these two traits compared to values registered by the other two hybrids in the same year (Table 2).

Table 2. Influence of the interaction year $\times$ hybrid on maize plant characteristics.

\begin{tabular}{|c|c|c|c|c|c|}
\hline Year & Hybrid & Plant Height (m) & Ear Insertion (m) & Leaf Length (m) & Leaves Number \\
\hline \multirow{3}{*}{2018} & Turda 332 & $2.28 \mathrm{a}$ & $1.10 \mathrm{bc}$ & $0.83 a$ & $5.31 \mathrm{a}$ \\
\hline & Turda 344 & $2.49 \mathrm{bc}$ & $1.24 \mathrm{c}$ & $0.87 \mathrm{~b}$ & $5.46 \mathrm{a}$ \\
\hline & PR37N01 & $2.38 \mathrm{ab}$ & $1.14 \mathrm{bc}$ & $0.84 \mathrm{a}$ & $5.40 \mathrm{a}$ \\
\hline \multirow{3}{*}{2019} & Turda 332 & $2.63 \mathrm{~cd}$ & $1.01 \mathrm{ab}$ & $0.87 \mathrm{~b}$ & $6.08 \mathrm{~b}$ \\
\hline & Turda 344 & $2.73 \mathrm{~d}$ & $1.13 \mathrm{bc}$ & $0.84 \mathrm{a}$ & $5.90 \mathrm{~b}$ \\
\hline & PR37N01 & $2.63 \mathrm{~cd}$ & $0.99 \mathrm{ab}$ & $0.84 \mathrm{a}$ & $5.84 \mathrm{~b}$ \\
\hline \multirow{3}{*}{2020} & Turda 332 & $2.81 \mathrm{~d}$ & $1.15 \mathrm{bc}$ & $0.96 \mathrm{~d}$ & $5.40 \mathrm{a}$ \\
\hline & Turda 344 & $2.76 \mathrm{~d}$ & $1.06 \mathrm{ab}$ & $0.95 \mathrm{~d}$ & $5.42 \mathrm{a}$ \\
\hline & PR37N01 & $2.62 \mathrm{~cd}$ & $0.92 \mathrm{a}$ & $0.90 \mathrm{c}$ & $6.00 \mathrm{~b}$ \\
\hline
\end{tabular}

Note: Differences between means followed by common letters are not significant at $p>0.05$ (Duncan test).

Plant height registered by the maize hybrids "Turda 332" and "Turda 344" in 2020, as well as by "Turda 344" in 2019 was significantly higher than values registered by these hybrids in 2018. Similarly, plant height of the hybrid "PR37N01" in 2018 was significantly lower compared to the one registered by the same hybrid in the next two years. Leaf length was significantly higher for the two Turda hybrids in 2020 compared to values registered in the other experimental years by either of the three hybrids tested. As for the leaf number, all three hybrids presented a significantly higher number in 2019 compared to 2018 (Table 2).

\subsection{Quantitative and Qualitative Productivity Components of Maize}

Two quantitative productivity traits of maize (TKW and yield) were both influenced highly significantly by the three experimental factors: years, hybrid and fertilization regime. Also, these two productivity components were also influenced significantly by bi-partite interaction years $\times$ hybrid and respectively years $\times$ fertilization. However, only TKW was also significantly influenced by tripartite interaction between these factors. Compared to these components, the hectoliter mass was influenced significantly only by the hybrid and not by the other factors or their interactions (Figure 4). This suggests that, while fertilization has the potential to maximize the yield, the hectoliter mass is less susceptible to variation under environmental conditions or inputs.

Quality of the grains was significantly influenced by all three factors, as well as by their bipartite and tripartite interaction. These indicated that the agronomic components could be enhanced through inputs (Figure 4), but fertilization can be optimized and given genotypes. From the three maize hybrids tested, "Turda 332" led to the obtaining of the highest yield $(10,607.98 \pm 2657.89 \mathrm{~kg} / \mathrm{ha})$, followed by “PR37N01” (10,477.56 $\pm 2059.38 \mathrm{~kg} / \mathrm{ha})$ (Table S2). 


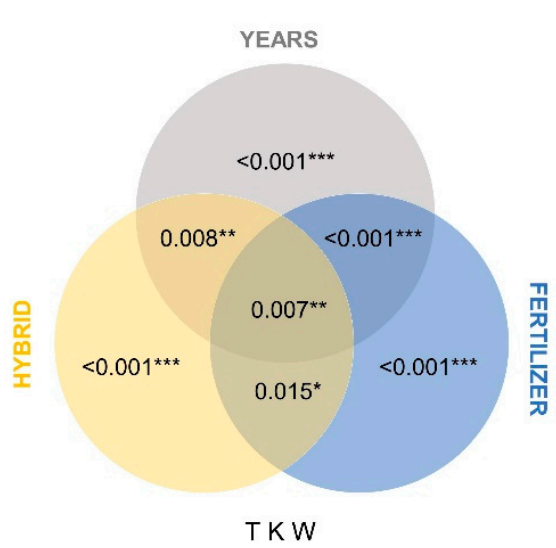

(a)

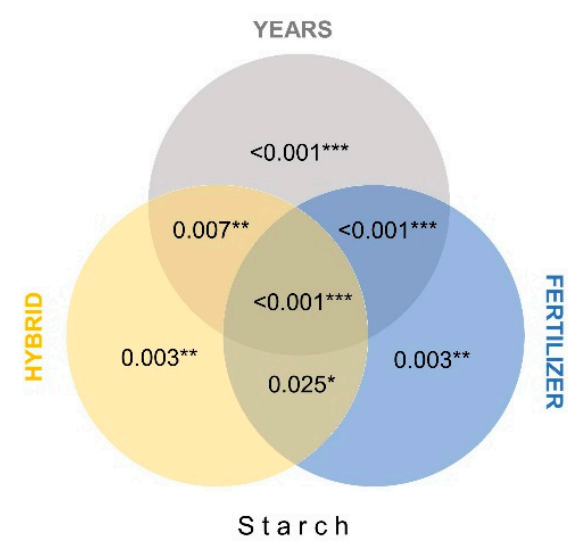

(d)

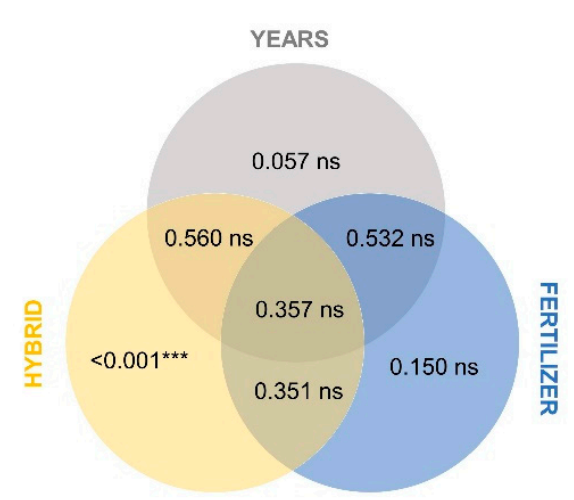

HLM

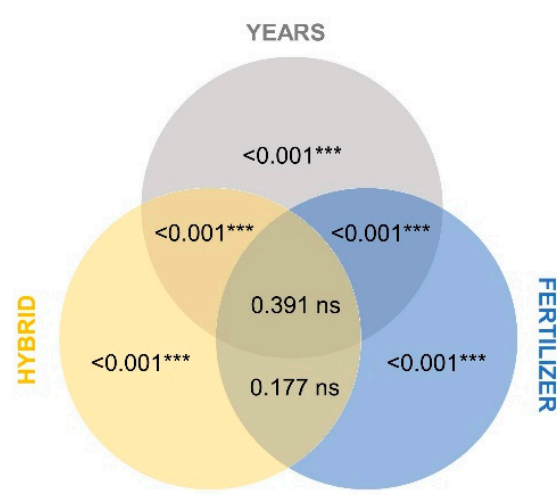

Yield

(b)

(c)

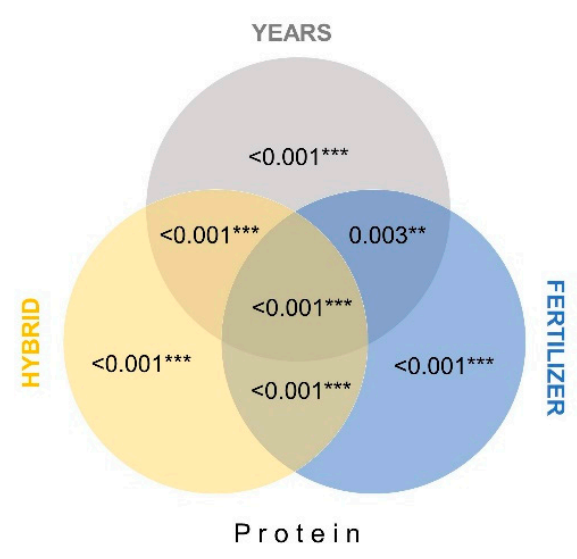

(e)

Figure 4. Venn diagram depicting the influence of experimental factors and their interaction on maize quantitative productivity components: (a) thousand kernels weight; (b) hectoliter mass; (c) yield; (d) starch content; (e) protein content. Numbers represent $p$-values according to three-way ANOVA results; significance levels assigned $p>0.05$ (ns), $p<0.05\left(^{*}\right)$, $\left.p<0.01{ }^{(* *)}, p<0.001{ }^{(* *}\right)$.

A more detailed analysis on the influence of fertilization gradient across experimental years revealed that various fertilizers could enhance productivity components under certain climatic conditions. In the year 2018, all five fertilization regimes ensured significantly higher yields compared to the control, represented by basal fertilization at sowing followed by phasic application of calcium ammonium nitrate. In the year 2020, again, four fertilization regimes ensured significantly higher yields compared to the control (Table 3 ). 
Table 3. Influence of the interaction year $\times$ fertilization regime on productivity traits of maize (2018-2020).

\begin{tabular}{|c|c|c|c|c|c|}
\hline Year & Fertilization Regime & TKG (g) & Yield (kg/ha) & Starch $(\%)$ & Protein $(\%)$ \\
\hline \multirow{6}{*}{2018} & Basal + CAN & $326.78 \mathrm{Ct}$. & 9897.67 Ct. & $72.49 \mathrm{Ct}$. & $7.24 \mathrm{Ct}$. \\
\hline & Eurofertil Top 51 NPK + CAN & 341.67 & $11,066.33^{* * *}$ & $78.08 * * *$ & 7.38 \\
\hline & Basal + Synertec NK35 N-process & 331.89 & $10,764.11^{* *}$ & 72.71 & $7.69 *$ \\
\hline & Basal + CAN + Fertiactyl Starter & 330.89 & $10,843.22 * *$ & 72.81 & 7.32 \\
\hline & $\begin{array}{c}\text { Basal + CAN + Rootip Basic + } \\
\text { Energevo }\end{array}$ & $305.22 *$ & $11,935.11^{* * *}$ & 73.27 & $7.68 *$ \\
\hline & NovaTec Classic & $288.33 *$ & $11,280.78^{* * *}$ & 73.25 & $6.77^{*}$ \\
\hline \multirow{6}{*}{2019} & Basal + CAN & $244.56 \mathrm{Ct}$. & $7528.00 \mathrm{Ct}$. & $60.55 \mathrm{Ct}$ & $8.24 \mathrm{Ct}$. \\
\hline & Eurofertil Top 51 NPK + CAN & 259.00 & 7650.89 & 60.49 & $8.71 * *$ \\
\hline & Basal + Synertec NK35 N-process & 252.22 & 7456.56 & 60.05 & $8.69 *$ \\
\hline & Basal + CAN + Fertiactyl Starter & 252.22 & 7443.11 & 59.88 & 8.32 \\
\hline & $\begin{array}{c}\text { Basal + CAN + Rootip Basic + } \\
\text { Energevo }\end{array}$ & $263.00 *$ & 7499.33 & 61.94 & $8.66^{*}$ \\
\hline & NovaTec Classic & 253.67 & 7315.78 & 61.89 & $7.75^{*}$ \\
\hline \multirow{6}{*}{2020} & Basal + CAN & $300.00 \mathrm{Ct}$. & $11,667.44 \mathrm{Ct}$. & $73.08 \mathrm{Ct}$. & $7.02 \mathrm{Ct}$. \\
\hline & Eurofertil Top 51 NPK + CAN & $317.78 *$ & $12,558.00 * *$ & 74.08 & 6.77 \\
\hline & Basal + Synertec NK35 N-process & 306.67 & $13,420.33^{* * *}$ & $76.48^{* *}$ & $6.56 *$ \\
\hline & Basal + CAN + Fertiactyl Starter & 300.00 & $12,523.22 * *$ & 73.59 & 7.22 \\
\hline & $\begin{array}{c}\text { Basal + CAN + Rootip Basic + } \\
\text { Energevo }\end{array}$ & $317.78 *$ & $12,020.00$ & 72.66 & 7.12 \\
\hline & NovaTec Classic & 302.22 & $12,405.89 *$ & $75.95 *$ & $6.43 *$ \\
\hline & LSD $p 5 \%$ & 16.81 & 576.96 & 2.22 & 0.35 \\
\hline & $\mathrm{LSD} p 1 \%$ & 22.21 & 762.51 & 2.93 & 0.46 \\
\hline & LSD $p 0.1 \%$ & 28.72 & 985.76 & 3.79 & 0.59 \\
\hline
\end{tabular}

Note: Fisher's Least Significant Difference test significance levels assigned $p<0.05\left({ }^{*}\right), p<0.01\left({ }^{* *}\right), p<0.001\left({ }^{* *}\right)$; Ct.-Control.

On average, the highest yield was obtained in the year $2020(12,432.48 \pm 979.08 \mathrm{~kg} / \mathrm{ha})$ and the highest TKW was obtained in 2018 (320.80 $\pm 32.19 \mathrm{~g})$. In the year 2019, was registered both the lowest yield $(7482.28 \pm 579.03 \mathrm{ka} / \mathrm{ha})$ as well as lowest TKW $(254.11 \pm 33.38 \mathrm{~g})$. The highest yield was obtained by the hybrid "Turda 332", but the highest TKW and HLM by hybrid "PR37N01" (Table S2). The highest starch content of grains was registered in $2020(74.31 \%)$ and associated with the lowest protein content $(6.85 \%)$. The highest protein content was registered in 2019 (8.39\%) when the yield was lowest. The hybrid "PR37N01" was characterized by higher average starch content, while the hybrid "Turda 344 " by higher protein content compared to the other hybrids (Table S3).

Compared to the control, application of Eurofertil Top 51 NPK + CAN in 2018 ensured significantly higher starch levels compared to the control. In 2020, application of Basal complex fertilizer + Synertec NK35 N-process ensured significant increase in starch content, but at the same time, significant decrease in protein content compared to the control (Table 3).

\subsection{Disease and Pest Incidence}

All three studied factors exercised a significant influence over Fusarium sp., and Ostrinia nubilalis incidence on maize ears, while tripartite interaction between these did not exercise a significant influence. The interaction between experimental years and hybrid was highly significant for disease and pest incidence (Figure 5). 


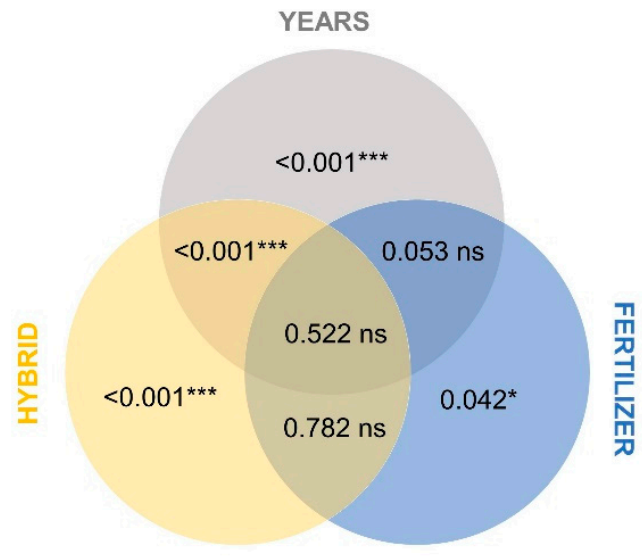

Fusarium

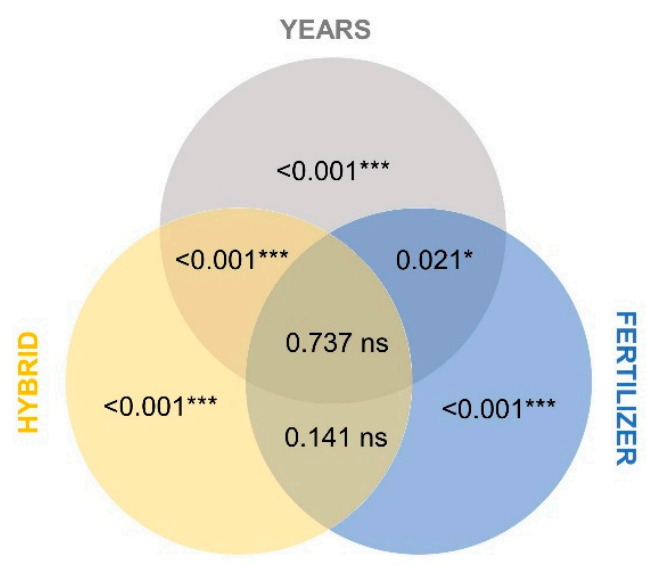

Ostrinia

(a)

(b)

Figure 5. Venn diagram depicting the influence of experimental factors and their interaction on maize crop health: (a) Fusarium sp. incidence; (b) Ostrinia nubilalis incidence. Numbers represent $p$-values according to three-way ANOVA results; significance levels assigned $p>0.05(\mathrm{~ns}), p<0.05\left(^{*}\right), p<0.001\left(^{* * *}\right)$.

Compared to the three-year average, the Fusarium sp. incidence was significantly lower for the two Turda hybrids in 2020, and significantly higher for the same hybrids in 2018 (Table 4).

Table 4. Influence of the interaction hybrid $\times$ year on disease and pest incidence in maize.

\begin{tabular}{|c|c|c|c|}
\hline Hybrid & Year & Fusarium sp. (\%) & Ostrinia nubilalis (\%) \\
\hline \multirow{4}{*}{ Turda 332} & Average (Ct.) & 50.46 & 47.80 \\
\hline & 2018 & $75.11^{* * *}$ & $64.89^{* * *}$ \\
\hline & 2019 & 40.28 & $56.56^{* *}$ \\
\hline & 2020 & $36.00 *$ & $21.94 *$ \\
\hline \multirow{4}{*}{ Turda 344} & Average (Ct.) & 30.04 & 36.80 \\
\hline & 2018 & $53.78^{* *}$ & $49.33^{* * *}$ \\
\hline & 2019 & 20.06 & $42.67 *$ \\
\hline & 2020 & $16.28 *$ & $18.39 *$ \\
\hline \multirow{4}{*}{ PR37N01 } & Average (Ct.) & 20.37 & 26.54 \\
\hline & 2018 & 29.78 & 31.11 \\
\hline & 2019 & 12.56 & 27.22 \\
\hline & 2020 & 18.78 & $21.28 *$ \\
\hline \multicolumn{2}{|c|}{ LSD $p 5 \%$} & 10.51 & 4.71 \\
\hline \multicolumn{2}{|c|}{ LSD $p 1 \%$} & 15.49 & 6.89 \\
\hline \multicolumn{2}{|c|}{ LSD $p 0.1 \%$} & 24.12 & 10.54 \\
\hline
\end{tabular}

Note: Fisher's Least Significant Difference test significance levels assigned $p<0.05\left(^{*}\right), p<0.01\left(^{* *}\right), p<0.001\left(^{* * *}\right)$ Ct.-Control.

Similarly, Ostrinia nubilalis incidence followed the same trend by displaying highly significant infestation for the two Turda hybrids in 2018 and significantly lower in 2020 compared to the control (Table 4).

Overall, both Fusarium sp. and Ostrinia nubilalis incidence on maize ears was higher in 2018 and lower in 2020. The lowest incidence was identified for "PR37N01" among the three genotypes studied (Table S4), which might indicate a lower susceptibility of this genotype. 
Analysis revealed that Fusarium infection of maize ears was lowest under the Basal + CAN fertilization regime, while Ostrinia nubilalis infestation frequency was highly significantly lower than the control under fertilizer regime Basal + CAN + Rootip Basic + Energevo (Table 5).

Table 5. Influence of fertilization regime on disease and pest incidence in maize.

\begin{tabular}{|c|c|c|}
\hline Fertilization Regime & Fusarium sp. (\%) & Ostrinia nubilalis (\%) \\
\hline Basal + CAN & $31.96 \mathrm{Ct}$. & 40.93 Ct. \\
\hline Eurofertil Top 51 NPK + CAN & 32.56 & 39.52 \\
\hline $\begin{array}{l}\text { Basal + Synertec NK35 } \\
\text { N-process }\end{array}$ & 37.19 & 41.3 \\
\hline $\begin{array}{l}\text { Basal + CAN + Fertiactyl } \\
\text { Starter }\end{array}$ & $38.74 *$ & 36.33 \\
\hline $\begin{array}{l}\text { Basal + CAN + Rootip Basic + } \\
\text { Energevo }\end{array}$ & 28.78 & $25.7^{* * *}$ \\
\hline NovaTec Classic & 32.52 & 38.48 \\
\hline $\mathrm{LSD} p 5 \%$ & 6.18 & 5.16 \\
\hline LSD $p 1 \%$ & 8.16 & 6.82 \\
\hline LSD $p 0.1 \%$ & 10.55 & 8.81 \\
\hline
\end{tabular}

\section{Discussion}

According to the results presented, fertilizer regimes options available today confer the possibility to farmers of enhancing traits of interest according to desired outcomes. Thus, increased biomass, or yields, low disease and pest incidence, high starch or protein content of grains could be obtained by selecting certain combination of fertilizers. The application of basal fertilization in conjunction of CAN, a classic and well-established fertilization regime was outperformed by the fertilization regimes based on the novel fertilizers, combination of several fertilizers or complementing the Basic + CAN, regarding yield and grain quality. This could be attributed to a more complete range of nutrients supplied and higher levels of macronutrients that can be associated with higher overall agronomic performance of maize, according to the current study performed in conditions from the Transylvanian Plain, that experiences continental climate with variations from one year to another.

It remains an important aspect to consider that experimental years had a highly significant influence over 11 out of 12 agronomic components of maize, particularly yield, grain quality and crop health. Low yield registered in 2019 could be attributed to the drought from the summer months of June and July, when very low precipitation values were reported concomitantly with high temperatures. According to the Ministry of Agriculture and Rural Development from Romania, the national average year for maize in 2019 was lower, only $6.502 \mathrm{~kg} / \mathrm{ha}$, compared to the average national yield from the previous year, of $7.644 \mathrm{~kg} / \mathrm{ha}$ [3]. The higher yield of 2020 can also be associated with climatic conditions, since the months of June and July of the respective year were more abundant in precipitations, while also cooler compared to the two previous years enabling the expression of productivity potential of the hybrids tested. In this regard, the results seem to suggest that the fertilizer regime chosen can significantly enhance the productivity components of maize under favorable years for this crop.

Around the world, optimization of fertilizer use for increased production parameters of maize remains an important subject of research that enjoys attention [5,9,31-35]. Besides application of mineral fertilizers, productivity components of maize were shown to be positively influenced by biostimulants [36] and foliar micronutrient application [12,37,38] One way to optimize the nutrient use by the crop might be to ensure supply in quantity and at the moment when plants need it, in short, to synchronize the supply with plant demands [11,13]. Differences between genotypes in the uptake and nutrient efficiency use 
can be attributed to pattern of accumulation and partitioning across growing stages and plant parts [10].

Over a half century of maize crop research, yield per hectare increased continuously, with about half of the gain attributed to genetic improvement [10]. Thus, the role of genotypes and their adaptability to local conditions can prove essential performance criteria for maize genotypes, especially for the Transylvanian Plain, which experiences a continental climate [39]. The results of the study presented here have highlighted that genotype had a significant influence on all agronomic components, while genotype $\times$ experimental year interaction also influenced significantly several key agronomic components.

Historically, the use of NPK received the most attention as a means to enhance yields, while the use of micronutrients to increase productivity parameters of crops has been less considered, yet these are just as important for achieving balanced nutrient stewardship [13]. From macronutrients, nitrogen use efficiency has been a subject of attention for a long time in agronomic science, due to its foremost influence on maize yield. There is evidence that the benefits of delaying a part of nitrogen $(\mathrm{N})$ application to late vegetative stages do not bring additional benefit for the crop [6]. Ca and $\mathrm{Mg}$ are macronutrients with a pivotal role in plant growth [11], while eight micronutrients are considered essential for healthy growth of plants in small doses and these are: $\mathrm{B}, \mathrm{Cl}, \mathrm{Cu}, \mathrm{Fe}, \mathrm{Mn}, \mathrm{Mo}, \mathrm{Ni}$ and $\mathrm{Zn}$. Research shows that the form in which micronutrients are found when applied to the crop have influence on availability, and thus on their impact on the crop growth [13]. Farmers would benefit from increased awareness on the importance of micronutrient application for their crops.

Basic fertilizers containing either one-two components have certain trace elements and thus, mineral fertilizers can increase the level of trace elements in plants and soil, either essential or non-essential. Experimental results have shown that incremental potassium fertilization doses led to a linear increase of essential nutrients such as $\mathrm{Ni}, \mathrm{Zn}$ and $\mathrm{Mn}$, while higher $\mathrm{N}$ fertilization increased $\mathrm{Mn}$ and Fe. Potassium and Nitrogen were found to have antagonistic effect on Fe:Zn and Fe:Mn ratios in maize plants [40].

Recent research has demonstrated the lasting impact of P [41] and NP starter fertilization [42] on maize crop, results indicating as optimal localized fertilizer to be applied at $5 \mathrm{~cm}$ to the side and below the kernel at sowing [42]. Localized fertilization to ensure uniform plants and boost the crop start is perhaps one of the most interesting approaches for sustainable use of mineral fertilizers.

A comparative study conducted in the United States on maize hybrids created between 1960 and 2000 by DuPont Pioneer identified that newer maize hybrids had higher nutrient uptake capacity compared to older ones. The study also managed to put in evidence the differences in nutrient concentration across plant growth stages and plant-fraction levels. Results showed that macronutrients NP followed overall a similar trend of concentration in tissue that was contrasting with $\mathrm{K}$ pattern. Although overall accumulation of $\mathrm{N}$ in whole maize plants increased until dent stage, in plant fractions these had a specific pattern. Thus, at silking the $\mathrm{N}$ accumulation reached the peak in stalk, leaves and tassel. In vegetative tissue, accumulation of $\mathrm{P}$ reached the peak at the silking-blistering stage and decreased once with plant maturity. Similarly, K accumulation in tissues increased until blister stage followed by a decline. Notably, the K content was higher than $\mathrm{N}$ or $\mathrm{P}$ in cobs. For grains, nutrients accumulation and concentration increased with maturity [10]. Under increased NPK supply, maize shows delayed leaf senescence that ensure postsilking nutrient accumulation and remobilization that translates into higher yields. Modern genotypes that retain green foliage longer exhibit higher post-silking $\mathrm{N}$ accumulation and higher dry grain matter levels [8].

Research conducted in Brazil on four transgenic maize hybrids has put in evidence that macronutrient uptake displayed some differences when subject to high versus medium fertilization investment levels. Results showed that, although under high-fertilizer investment the total dry mater yield of plant shoot was higher, the harvest index was lower compared to medium investment. At the end of growing season, an average of $53 \% \mathrm{~N}$ found in the plant was allocated to grains [32]. A study conducted in Mexico on maize 
hybrid AS-757 cultivated for grain and silage showed that N-190 dose was optimal for delaying inflorescence and obtaining maximum grain yields as well as grain to forage and cobs to stover ratios [43]. An experiment conducted in West Bengal, India, on three maize hybrids subject to nine fertilizer regimes representing $50-150 \%$ of the recommended dose and omission of one of the macronutrients (either N, P or K), demonstrated that NPK levels exercised a significant influence on grain yield while incremental NPK levels caused increase in saturated fatty acids concomitantly with decrease of unsaturated fatty acids in maize oil [44]. In addition, omission of $\mathrm{N}$ was the most consequential on post-silking and total dry matter and nutrient accumulation followed by $\mathrm{P}$ and $\mathrm{K}$ omission [8], confirming the long-standing notion that maize is highly dependent on NPK fertilization.

\section{Conclusions}

This study assessed the agronomic performance of three maize hybrids in conditions of the Transylvanian Plain, under a fertilizer regime gradient meant to compare traditional fertilization approach with novel options of fertilization available to farmers.

Results showed that fertilization influenced significantly the yield, TKW, grain quality (starch and protein content) and crop health (Fusarium and Ostrinia incidence).

From the six fertilizer regimes tested, the basal fertilization at sowing (NP) coupled with calcium ammonium nitrate at 4-8 leaves was outperformed by all other five fertilizer regimes, that ensured yields of $>10 \mathrm{t} / \mathrm{ha}$. This proved the potential of novel fertilization products and approaches to maximize the productivity potential of the genotypes tested.

Experimental year influenced significantly eleven out of twelve agronomic components studied, indicating that fertilization can positively influence the expression of productivity potential of maize genotypes in favorable years for this crop.

Supplementary Materials: The following are available online at https:/ /www.mdpi.com/article/10 .3390/agriculture11090896/s1, Table S1: Influence of experimental gradients on plant characteristics; Table S2: Influence of experimental gradients on agronomic productivity components of maize; Table S3: Influence of experimental gradients on grain quality of maize; Table S4: Influence of experimental gradients on disease and pest incidence.

Author Contributions: Conceptualization, G.B., M.M.D. and L.A.S.; methodology, G.B., M.M.D. and L.A.S.; software, L.A.S.; validation, L.A.S., M.M.D. and L.S.; formal analysis, G.B., L.S., M.M.D. and L.A.S.; investigation, G.B. and L.A.S.; resources, G.B., L.A.S. and L.S.; data curation, L.A.S.; writing—original draft preparation, I.C. and L.A.S.; writing—review and editing, L.A.S., M.M.D., G.B., L.S., I.C.; visualization, L.A.S. and I.C.; supervision, L.A.S. and M.M.D. All authors have read and agreed to the published version of the manuscript.

Funding: This research received no external funding.

Institutional Review Board Statement: Not applicable.

Informed Consent Statement: Not applicable.

Data Availability Statement: Not applicable.

Conflicts of Interest: The authors declare no conflict of interest.

\section{References}

1. FAOSTAT. Available online: http://www.fao.org/faostat/en/\#rankings/countries_by_commodity (accessed on 18 August 2021).

2. Statistics / Eurostat. Available online: https://ec.europa.eu/eurostat/databrowser/view/tag00093/default/table?lang=en (accessed on 18 August 2021).

3. Porumb-Ministerul Agriculturii si Dezvoltarii Rurale. Available online: https://www.madr.ro/culturi-de-camp/cereale/ porumb.html (accessed on 18 August 2021).

4. Cheverdin, A.; Piskareva, L. Influence of mineral fertilizers and growth regulators for maize yield. J. Agric. Environ. 2020, 1-4. [CrossRef]

5. Adhikary, B.H.; Baral, B.R.; Shrestha, J. Productivity of winter maize as affected by varieties and fertilizer levels. Int. J. Appl. Biol. 2020, 4, 85-93. [CrossRef]

6. Nafziger, E.; Rapp, D. Corn yield response to late-split nitrogen fertilizer. Agron. J. 2021, 113, 527-536. [CrossRef] 
7. Tenorio, F.A.M.; McLellan, E.L.; Eagle, A.J.; Cassman, K.G.; Andersen, D.; Krausnick, M.; Oaklund, R.; Thorburn, J.; Grassini, P. Benchmarking impact of nitrogen inputs on grain yield and environmental performance of producer fields in the western US Corn Belt. Agric. Ecosyst. Environ. 2020, 294, 106865. [CrossRef]

8. Ray, K.; Banerjee, H.; Dutta, S.; Sarkar, S.; Murrell, T.S.; Singh, V.K.; Majumdar, K. Macronutrient Management Effects on Nutrient Accumulation, Partitioning, Remobilization, and Yield of Hybrid Maize Cultivars. Front. Plant Sci. 2020, 11, 1307. [CrossRef] [PubMed]

9. Ibrahim, K.; Wang, Q.; Wang, L.; Zhang, W.; Peng, C.; Zhang, S. Determining the Optimum Level of Soil Olsen Phosphorus and Phosphorus Fertilizer Application for High Phosphorus-Use Efficiency in Zea mays L. in Black Soil. Sustainability 2021, $13,5983$. [CrossRef]

10. Woli, K.P.; Sawyer, J.E.; Boyer, M.J.; Abendroth, L.J.; Elmore, R.W. Corn Era Hybrid Macronutrient and Dry Matter Accumulation in Plant Components. Agron. J. 2018, 110, 1648-1658. [CrossRef]

11. Ciampitti, I.A.; Vyn, T.J. Maize Nutrient Accumulation and Partitioning in Response to Plant Density and Nitrogen Rate: II. Calcium, Magnesium, and Micronutrients. Agron. J. 2013, 105, 1645-1657. [CrossRef]

12. Brankov, M.; Simić, M.; Dolijanović, Ž.; Rajković, M.; Mandić, V.; Dragičević, V. The Response of Maize Lines to Foliar Fertilizing. Agriculture 2020, 10, 365. [CrossRef]

13. Reyes Gaige, A.; Rowe, B.; Jurin, V. Assessment of Efficiency of Nutrient Uptake of Different Sources of Zn, Mn, Cu and B in Zea mays. Agriculture 2020, 10, 247. [CrossRef]

14. Moraru, P.I.; Rusu, T.; Bogdan, I.; Pop, A.; Coste, C.; Duda, B.; Sälägean, T.; Sopterean, M.; Ivan, I. The Influence of Slope Morphology upon the Thermic Regime of Soil andManagement Practices in the Transylvanian Plain. Bull. Univ. Agric. Sci. Vet. Med. Cluj-Napoca Agric. 2014, 71, 256-263. [CrossRef]

15. Embleton, C. Geomorphology of Europe; Macmillan International Higher Education: London, UK, 2016; ISBN 978-1-349-17346-4.

16. Bunescu, V.; Mihai, G.; Bunescu, H.; Man, I. Ecological Conditions and Soils from Transylvanian Plateau; Academic Press: Cluj-Napoca, Romania, 2005.

17. Malschi, D. Environment-Agriculture-Sustainable Development and Integrated Pest Management of Cereal Agroecosystems; Argonaut: Cluj-Napoca, Romania, 2007; ISBN 978-973-109-086-3.

18. Grecu, I.; Has, I.; Nagy, C. The 50th Anniversary 1957-2007 (ARDS Turda)—Results Obtained in the Reserach-Development Activity; Ela Design: Turda, Romania, 2007; ISBN 978-973-0-05311-1.

19. Romania Climate: Köppen-Geiger Climate Classification for Turda. Available online: https://en.climate-data.org/europe/ romania-185/ (accessed on 9 September 2021).

20. Chețan, F.; Rusu, T.; Chețan, C.; Moraru, P.I. Influence of soil tillage upon weeds, production and economical efficiency of corn crop. AgroLife Sci. J. 2016, 5, 36-43.

21. Naturevo-îngrășăminte, Semințe, Fertilizanți Foliari. Available online: https://www.naturevo.ro/ (accessed on 7 August 2021).

22. Solutiile Noastre-Nutritia Plantelor. Available online: https://ro.timacagro.com/categorie-produit/solutiile-noastre/ ?nutrition=2\&aff=1 (accessed on 17 August 2021).

23. Meier, U. BBCH Monograph — Growth Stages of Mono- and Dicotyledonous Plants; Julius Kühn-Institut (JKI): Quedlinburg, Germany, 2018; ISBN 978-3-95547-071-5. [CrossRef]

24. Soiuri, Hibrizi-Statiunea de Cercetare Dezvoltare Agricola Turda. Available online: https://scdaturda.ro/soiurihibrizi/ (accessed on 7 August 2021).

25. Corn Seeds-Pioneer. Available online: https://www.pioneer.com/us/search.html (accessed on 7 August 2021).

26. Seminte de Porumb Pioneer PR37N01. Available online: https://www.agronor.ro/seminte-de-porumb-pioneer-pr37n0125000 -seminte (accessed on 10 September 2021).

27. Granomat: Umidimetru Pentru Boabe întregi-Pfeuffer GmbH (Quality Control of Grain and Seeds). Available online: https: //www.pfeuffer.com/ro/produs/granomat (accessed on 7 August 2021).

28. TANGO FT-NIR Spectrometer. Available online: https://www.bruker.com/en/products-and-solutions/infrared-and-raman/ftnir-spectrometers / tango-ft-nir-spectrometer.html (accessed on 7 August 2021).

29. ISTIS Metodica. Available online: https://istis.ro/image/data/download/publicatii/MetodicaVAU.pdf (accessed on 7 August 2021).

30. OriginLab-Origin and OriginPro-Data Analysis and Graphing Software. Available online: https://www.originlab.com/ (accessed on 9 September 2021).

31. Njoroge, R.; Otinga, A.N.; Okalebo, J.R.; Pepela, M.; Merckx, R. Maize (Zea mays L.) Response to Secondary and Micronutrients for Profitable N, P and K Fertilizer Use in Poorly Responsive Soils. Agronomy 2018, 8, 49. [CrossRef]

32. Silva, C.G.M.; de Resende, Á.V.; Gutiérrez, A.M.; Moreira, S.G.; Borghi, E.; Almeida, G.O. Macronutrient uptake and export in transgenic corn under two levels of fertilization. Pesqui. Agropecu. Bras. 2018, 53, 1363-1372. [CrossRef]

33. Borase, C.L.; Lomte, D.M.; Thorat, S.D.; Dhonde, A.S. Response of Kharif maize (Zea mays L.) to micronutrients. J. Pharmacogn. Phytochem. 2018, 7, 482-484.

34. Mahmood, Y.A.; Ahmed, F.W.; Mohammed, I.Q.; Wheib, K.A. Effect of Organic, Mineral Fertilizers and Foliar Application of Humic Acid on Growth and Yield of Corn (Zea mays L.). Indian J. Ecol. 2020, 47, 39-44.

35. Al-Budeiri, M.H.; Al-Shami, Y.A.O. Effect of addition mineral, organic and bio-fertilizers on nitrogen, phosphorous, potassium concentration and protein of corn crop (Zea mays L.). IOP Conf. Ser. Earth Environ. Sci. 2021, 735, 012062. [CrossRef] 
36. Kapela, K.; Sikorska, A.; Niewęgłowski, M.; Krasnodębska, E.; Zarzecka, K.; Gugała, M. The Impact of Nitrogen Fertilization and the Use of Biostimulants on the Yield of Two Maize Varieties (Zea mays L.) Cultivated for Grain. Agronomy 2020, 10, 1408. [CrossRef]

37. Razhan, B.M.; Ghafoor, A.M.R. Influence of Foliar Application of some Micronutrients on Maize Kernel Yield and Nutrient content. J. Zankoy Sulaimani 2020, 22, 77-88.

38. Stewart, Z.P.; Paparozzi, E.T.; Wortmann, C.S.; Jha, P.K.; Shapiro, C.A. Effect of Foliar Micronutrients (B, Mn, Fe, Zn) on Maize Grain Yield, Micronutrient Recovery, Uptake, and Partitioning. Plants 2021, 10, 528. [CrossRef]

39. Ghețe, A.B.; Haș, V.; Vidican, R.; Copândean, A.; Ranta, O.; Moldovan, C.M.; Crișan, I.; Duda, M.M. Influence of Detasseling Methods on Seed Yield of Some Parent Inbred Lines of Turda Maize Hybrids. Agronomy 2020, 10, 729. [CrossRef]

40. Wyszkowski, M.; Brodowska, M.S. Potassium and Nitrogen Fertilization vs. Trace Element Content of Maize (Zea mays L.). Agriculture 2021, 11, 96. [CrossRef]

41. Szulc, P.; Ambroży-Deregowska, K.; Waligóra, H.; Mejza, I.; Grześ, S.; Zielewicz, W.; Wróbel, B. Dry Matter Yield of Maize (Zea mays L.) as an Indicator of Mineral Fertilizer Efficiency. Plants 2021, 10, 535. [CrossRef]

42. Szulc, P.; Bocianowski, J.; Nowosad, K.; Bujak, H.; Zielewicz, W.; Stachowiak, B. Effects of NP Fertilizer Placement Depth by Year Interaction on the Number of Maize (Zea mays L.) Plants after Emergence Using the Additive Main Effects and Multiplicative Interaction Model. Agronomy 2021, 11, 1543. [CrossRef]

43. Medina-Cuéllar, S.E.; Tirado-González, D.N.; Portillo-Vázquez, M.; Orozco-Cirilo, S.; López-Santiago, M.A.; Vargas-Canales, J.M.; Medina-Flores, C.A.; Salem, A.Z.M. Optimal Nitrogen Fertilization to Reach the Maximum Grain and Stover Yields of Maize (Zea mays L.): Tendency Modeling. Agronomy 2021, 11, 1354. [CrossRef]

44. Ray, K.; Banerjee, H.; Dutta, S.; Hazra, A.K.; Majumdar, K. Macronutrients influence yield and oil quality of hybrid maize (Zea mays L.). PLoS ONE 2019, 14, e0216939. [CrossRef] [PubMed] 